\title{
Mammary epithelium disruption and mammary epithelial cell exfoliation during milking in dairy cows
}

\author{
L. Herve, ${ }^{*}$ H. Quesnel, ${ }^{*}$ V. Lollivier, ${ }^{*} \dagger$ J. Portanguen, ${ }^{*}$ R. M. Bruckmaier, $\ddagger$ and M. Boutinaud ${ }^{* 1}$ \\ *PEGASE, Agrocampus Ouest, INRA, 35590 Saint-Gilles, France \\ †Université Bretagne Loire, 35044 Rennes, France \\ †Veterinary Physiology, Vetsuisse Faculty, University of Bern, CH-3012 Bern, Switzerland
}

\begin{abstract}
The presence of mammary epithelial cells (MEC) in the milk of ruminants indicates that some MEC are shed from the mammary epithelium; however, the mechanisms that regulate the MEC exfoliation process are not known. Through the release of oxytocin, prolactin, and cortisol and through oxytocin-induced mechanical forces on the mammary epithelium, milking could participate in regulating the MEC exfoliation process. The aims of the present study were to determine the rate of MEC exfoliation throughout milking and to investigate its relationship to mammary epithelium integrity and milking-induced hormone release. Milk samples from 9 Holstein dairy cows producing $40.6 \pm 1.36 \mathrm{~kg}$ of milk/d were collected at the beginning (after 1 and $2 \mathrm{~min}$ ), in the middle, and at the end of milking. Milk MEC were purified using an immunomagnetic method. Blood samples were collected before, during, and after milking, and the oxytocin, prolactin, and cortisol concentrations in the samples were measured. Tight junction opening was assessed by plasma lactose concentration and the $\mathrm{Na}^{+}: \mathrm{K}^{+}$ratio in milk. The somatic cell count in milk varied during the course of milking; it decreased at the beginning of milking and then increased, reaching the highest values at the end of milking. Exfoliated MEC were present in all milk samples collected. The presence of MEC in the milk sample collected during min 1 of milking, likely corresponding to the cisternal milk fraction, suggests that MEC were exfoliated between milkings. The observed increase in the $\mathrm{Na}^{+}: \mathrm{K}^{+}$ratio in milk and in the plasma concentration of lactose indicated that disruption of mammary epithelium integrity occurred during milking. The MEC exfoliation rate at milking was not correlated with the variables describing milking-induced prolactin release but was negatively correlated with cortisol release, suggesting that cortisol
\end{abstract}

Received May 15, 2017.

Accepted August 19, 2017.

${ }^{1}$ Corresponding author: Marion.Boutinaud@inra.fr may play a role in limiting exfoliation. In conclusion, milking induced a disruption of the mammary epithelial barrier. Mammary epithelial cells may be continuously exfoliated between milkings or exfoliated during milking as a consequence of the oxytocin-induced mechanical forces and the disruption of mammary epithelium integrity.

Key words: dairy cow, mammary epithelial cell exfoliation, milking, tight junction

\section{INTRODUCTION}

Milk is synthesized by mammary epithelial cells (MEC), and milk yield is determined by the metabolic activity and the number of these cells in the mammary gland (Capuco et al., 2003; Boutinaud et al., 2004). The number of MEC in the mammary gland depends primarily on the balance between cell proliferation and apoptosis (Capuco et al., 2003). The presence of MEC in the milk of ruminants (Kitchen, 1981) indicates that MEC are shed from the mammary epithelium into milk. It was recently shown that the MEC exfoliation process participates in the regulation of MEC number in the udder and thus in milk yield variations (Herve et al., 2016). The mechanisms that regulate the MEC exfoliation process, however, are currently unknown. The MEC exfoliation process could be linked to a disruption of mammary epithelium integrity. Indeed, the MEC exfoliation rate increases concomitantly with an increase in the mammary epithelial permeability in response to various physiological, breeding, and environmental factors (Herve et al., 2016). It is not yet clear, however, whether the exfoliation of MEC is a consequence or a cause of tight junction opening.

Hormones released at milking in response to teat stimulation - namely oxytocin (OT), prolactin (PRL), and cortisol (Cort) - are likely to be involved in the regulation of mammary epithelium integrity (Nguyen and Neville, 1998). However, it is not yet known whether milking induces a disruption of the mammary epithelium integrity. Exogenous OT administered at supraphysiological doses was shown to induce tight 
junction opening in the bovine mammary gland (Allen, 1990; Wall et al., 2016), and it was speculated that tight junction integrity is compromised as a result of the mechanical forces caused by myoepithelial cell contraction (Stelwagen and Singh, 2014). The physiological OT release induced by milking also induces the contraction of myoepithelial cells and thus mechanical pressures on the mammary epithelium, allowing the complete removal of the alveolar milk. Prolactin also participates in the regulation of tight junctions because PRL stimulates tight junction formation in vitro (Stelwagen et al., 1999) and reduces tight junction permeability in rabbit and rat mammary glands (Linzell et al., 1975; Flint and Gardner, 1994). Finally, Cort is known to be a key regulator of mammary epithelium integrity; it stimulates tight junction formation and maintenance in vitro (Zettl et al., 1992; Singer et al., 1994), is necessary for tight junction closure in vivo during the transition from pregnancy to lactation in mice (Nguyen et al., 2001), and reduces tight junction permeability in vivo in the bovine mammary gland (Stelwagen et al., 1998).

The milking-induced release of OT could disrupt mammary epithelium integrity during milking, whereas PRL and Cort, which are also released upon milking, could reduce mammary epithelial permeability. We therefore hypothesized that milking, through the release of OT, PRL, and Cort and the OT-induced mechanical forces on the mammary epithelium, could play a role in regulating the MEC exfoliation process by modulating the integrity of the mammary epithelium. Thus, the aim of the present study was to determine the rate of MEC exfoliation during the time course of milking and to investigate the relationships between milking-induced hormone release, mammary epithelium integrity, and the MEC exfoliation process in dairy cows.

\section{MATERIALS AND METHODS}

All procedures used on animals were approved by the local Ethics Committee in Animal Experiment of Rennes (France) in compliance with French regulations (decree no. 2001-464; May 29, 2001; https://www.legifrance .gouv.fr/eli/decret/2001/5/29/AGRG0001697D/jo/ texte).

\section{Animals and Experimental Procedures}

Nine multiparous Holstein dairy cows (lactation 2 to 5 ), at peak lactation (57 \pm 5 DIM) and producing 40.6 $\pm 1.36 \mathrm{~kg}$ of milk/d at the beginning of the experiment, were used in this study. The cows were selected to have a low SCC; thus, they presented on average 36 $\pm 11 \times 10^{3}$ cells $/ \mathrm{mL}$ of milk before the beginning of the experiment. The experiment was conducted at the INRA experimental farm (UMR PEGASE, Le Rheu, France). Two weeks before the beginning of the experiment, the cows were housed in individual tiestalls to allow them to adapt to their new environment. The cows were fed according to the INRA recommendations and milked twice a day at 0700 and $1700 \mathrm{~h}$. The milking routine included teat cleaning for approximately 30 $\mathrm{s}$ and foremilk hand milking to confirm the absence of mastitis, indicated by the absence of clotted milk. During one morning milking (after a routine 14-h milking interval), milk samples were collected separately each minute using 2 milking devices alternately. Milk yield was recorded each minute, and a milk sample $(50 \mathrm{~mL})$ was taken for SCC and milk composition (fat, protein, and lactose content) determination using an infrared method (Lillab, Châteaugiron, France).

\section{Blood Sampling and Hormonal Assays}

The cows were surgically equipped with permanent catheters (Silclear medical-grade silicone tubing, 1.02 mm i.d., 2.16 mm o.d.; Degania Silicone, Degania Bet, Israel) inserted into the jugular vein. The catheters were inserted $4 \mathrm{~d}$ before the beginning of the experiment. On the day of the experiment, blood samples were collected before, during, and after the morning milking at -5 $-2,1,2,3,4,6,8,10,15,25,35$, and 45 min relative to milking unit attachment. Monovette syringes coated with sodium heparin (Sarstedt, Nümbrecht, Germany) were used to collect samples for the measurement of plasma OT and lactose concentrations, and Monovette syringes coated with EDTA (Sarstedt) were used to collect samples for the measurement of plasma PRL and Cort concentrations. The plasma was separated by centrifugation at $3,000 \times g$ for $15 \mathrm{~min}$ at $4^{\circ} \mathrm{C}$ and stored at $-20^{\circ} \mathrm{C}$ until analysis. Plasma OT concentration was measured using the ELISA method as described by Marnet et al. (1994). The plasma concentration of Cort was assessed using the ELISA method developed by Komara and Marnet (2009). The ELISA plates were coated with $200 \mu \mathrm{L} /$ well of mouse monoclonal antirabbit immunoglobulin antibody (Bertin Pharma, Montigny-le-Bretonneux, France) dissolved at $10 \mathrm{mg} / \mathrm{L}$ in $0.05 \mathrm{M}$ phosphate buffer and incubated at $4^{\circ} \mathrm{C}$ overnight. The plates were then washed, and $300 \mu \mathrm{L}$ of ELISA buffer (0.1 $M$ phosphate buffer containing 0.15 $M$ sodium chloride and $0.1 \% \mathrm{BSA}, \mathrm{pH} 7.4$ ) was added to each well. Cortisol was extracted from the plasma samples as follows: $100 \mu \mathrm{L}$ of plasma was mixed with $1 \mathrm{~mL}$ of absolute ethanol and incubated for $10 \mathrm{~min}$ on ice. After centrifugation at $8,000 \times g$ for $10 \mathrm{~min}$ at $4^{\circ} \mathrm{C}, 250 \mu \mathrm{L}$ of the supernatant was desiccated in a 
vacuum concentrator (SpeedVac Savant; ThermoFisher Scientific, Waltham, MA). The plates and plasma samples were stored at 4 and $-20^{\circ} \mathrm{C}$, respectively, until plasma Cort concentration analysis. After washing the plates with $300 \mu \mathrm{L}$ of washing buffer $(0.01 \mathrm{M}$ phosphate buffer containing $0.05 \%$ Tween 20, pH 7.4) per well, the plasma samples were reconstituted with $200 \mu \mathrm{L}$ of ELISA buffer. Then, $50 \mu \mathrm{L}$ of anticortisol antiserum (Sigma-Aldrich, St. Louis, MO) diluted 1:16,000 in ELISA buffer, $50 \mu \mathrm{L}$ of standard (ranging from 12,500 to $48 \mathrm{pg} / \mathrm{mL}$ ) or reconstituted plasma sample, and $50 \mu \mathrm{L}$ of Cort/peroxidase conjugate (diluted 1:2,000 in ELISA buffer) were dispensed into the plate wells. The plates were incubated at $4^{\circ} \mathrm{C}$ for $24 \mathrm{~h}$ and then washed twice. After $45 \mathrm{~min}$ of incubation with $200 \mu \mathrm{L}$ of 3-ethylbenzothiazoline-6-sulfonic-acid, the absorbance was read using a plate reader (VersaMax ELISA microplate reader; Molecular Devices, Sunnyvale, CA). Finally, plasma concentrations of PRL were measured by RIA as described by Bruckmaier et al. (1992). For the OT, Cort, and PRL assays, the detection limits were $48.5,19.5$, and $500 \mathrm{pg} / \mathrm{mL}$, respectively; the intraassay coefficients of variation were 1.9, 3.7, and $2.3 \%$, respectively; and the interassay coefficients of variation were $3.5,7.0$, and $8.4 \%$, respectively.

\section{Estimation of Mammary Epithelium Integrity}

Mammary epithelium integrity was estimated by measuring the lactose concentration in plasma. Plasma concentrations of lactose were measured using a multiparameter analyzer (Kone Instrument Corp., Espoo, Finland) and a kit for the detection of lactose/Dgalactose (Roche Diagnostics, Basel, Switzerland). Mammary epithelium integrity was also assessed by measuring the concentrations of various indicators in milk. First, a $100-\mu \mathrm{L}$ sample of milk was used for total milk $\mathrm{Na}^{+}$and $\mathrm{K}^{+}$analysis by atomic absorption spectrophotometry (Spectra AA220, Varian, Palo Alto, CA) as described by Murthy and Rhea (1967). Then, a 1.5-mL sample of skim milk was used for milk albumin content determination by radial immune diffusion with a specific kit (IDBiotech, Issoire, France) as previously described (Yart et al., 2013).

\section{Purification of Milk MEC}

Fresh milk samples collected at min 1, min 2, and the middle and end of milking were used for MEC purification using the immunomagnetic separation technique as described by Boutinaud et al. (2008) with some modifications. For each cow, the middle sample and the end sample differed depending on the dura- tion of milking: the middle sample corresponded to min $5 \pm 1$ of milking, and the end sample corresponded to min $7 \pm 2$ of milking. Fresh milk $(1.8 \mathrm{~kg}$ for the samples collected at min 1 and 2 and at the middle of milking, and $0.9 \mathrm{~kg}$ for the sample collected at the end of milking) was defatted by centrifugation, and the skim milk was removed to recover the milk somatic cell pellet. The total milk somatic cell suspension was analyzed for cell count determination using a Vi-Cell XR analyzer (Beckman Coulter, Brea, CA). The total milk somatic cell suspension was then used for milk MEC purification. First, Dynabeads (Pan Mouse IgG, Dynal Biotech, Invitrogen, Carlsbad, CA) were coated with a monoclonal mouse antibody directed against human cytokeratins 1, 5, 10, and 14 (clone 34ßE12; Dako, Trappes, France); the total milk cell suspension was then incubated with the antibody/beads complex. After $1 \mathrm{~h}$ of incubation, specifically bound cells corresponding to MEC were collected by placing the sample vials in a magnetic particle concentrator (MPC-S; Dynal Biotech, Invitrogen) for a few seconds followed by aspiration of the supernatant containing nonbound cells corresponding to leukocytes. The cell count and cell viability of the purified MEC suspension was analyzed using a Vi-Cell XR analyzer. The proportion of apoptotic cells in the purified milk MEC suspension was also determined by flow cytometry after staining of the cell suspension with the Annexin V/Dead Cell Apoptosis Kit (Molecular Probes Inc., Eugene, OR) according to the manufacturer's instructions. The cell suspension was diluted to approximately $5.0 \times 10^{5}$ cells per vial. After centrifugation at $500 \times g$ for $5 \mathrm{~min}$ at $4^{\circ} \mathrm{C}$, the supernatant was discarded, and the milk MEC were resuspended in $60 \mu \mathrm{L}$ of $1 \times$ annexin-binding buffer. Each MEC sample was separated into one control and one labeled sample of $25 \mu \mathrm{L}$ each. The labeled MEC samples were incubated with $25 \mu \mathrm{L}$ of labeling solution containing Alexa Fluor 488-annexin V and propidium iodide (Molecular Probes Inc.), and the control samples were incubated with $25 \mu \mathrm{L}$ of $1 \times$ annexin-binding buffer. After incubation for $15 \mathrm{~min}$ at room temperature, $250 \mu \mathrm{L}$ of $1 \times$ annexin-binding buffer was added to each sample. Finally, flow cytometry analysis was performed using a MACSQuant Analyzer 10 cytometer (Miltenyi Biotec, Bergisch Gladbach, Germany), and forward scatter, side scatter, and fluorescent staining properties were recorded. The number of events was stopped at 20,000 counts. The data were analyzed using MACSQuantify analysis software (Miltenyi Biotec). After exclusion of doublets and cell debris, the percentage of apoptotic MEC was determined by dot-plot analysis as the difference between the percentage of annexin $\mathrm{V} /$ propidium iodide-stained MEC in the labeled and control samples. 


\section{Calculations and Statistical Analyses}

The total number of somatic cells in the milk samples collected at each time point of milking was determined by multiplying the SCC by the milk yield. The MEC exfoliation rate at milking was defined as the sum of the number of exfoliated MEC obtained during each minute of milking. To calculate the exfoliation rate at milking, the number of MEC exfoliated during min 1, min 2 , and the middle and end of milking was determined by multiplying the measured MEC concentration in milk by the milk yield. The MEC concentration in milk was not measured at each minute of milking; thus, the number of MEC exfoliated during the remaining minutes was estimated by multiplying the average measured MEC concentration in milk by the yield of milk collected each minute.

The basal concentrations of OT, PRL, Cort, and lactose were determined as the average plasma concentrations of these compounds at 5 and 2 min before attachment of the milking unit. The OT, PRL, Cort, and lactose delta at milking were defined as the differences between the maximal and the basal concentrations. To describe the OT, PRL, and Cort release and the leakage of lactose at milking, we calculated the areas under the curve (AUC) from the beginning of milking to 15 min after the beginning of milking for OT, $45 \mathrm{~min}$ for PRL, $25 \mathrm{~min}$ for Cort, and $45 \mathrm{~min}$ for lactose after subtracting the basal concentrations of the compounds.

Because the duration of milking was different for each cow (the duration ranged from 7 to $13 \mathrm{~min}$ ), we created a 7-point time scale for the statistical analysis of milk yield and milk composition variables. The first 3 points corresponded to the first 3 min of milking of each cow, and the last 3 points corresponded to the last $3 \mathrm{~min}$ of milking of each cow. Point 4 in the scale corresponded to the mean value obtained for the intermediate minutes. For milk cell variables, the time scale consisted of 4 points (min 1, min 2, the middle of milking, and the end of milking). The SCC and cell variables were not normally distributed; therefore, $\log _{10}$ transformation of the data was performed before the analyses. The data were analyzed by ANOVA using the SAS Mixed procedure with repeated statements (SAS Institute Inc., Cary, NC). Time was used as the repeated parameter, and cow was used as the subject for repeated measures. The duration of milking of each cow was used as the covariate. In addition, for plasma hormone and lactose concentration data, the basal concentration was also used as the covariate. The time at which the hormone and lactose concentrations returned to the basal level was determined by the matched-pairs $t$-test using the SAS T-Test procedure. The SAS Corr procedure was used to generate the Spearman correlation coefficient $(\mathrm{r})$, which measured the strength of association between pairs of variables describing hormone release (basal and maximal concentrations, delta, and AUC), indicators of mammary epithelium integrity, and the MEC exfoliation rate at milking without specifying dependencies.

All data are expressed as the mean \pm standard error of the mean. For data on milk yield and composition and mammary epithelium integrity indicators, the tables show the means estimated by the statistical model. For plasma hormone and lactose concentration data, the graphs show the means estimated by the statistical model, and the tables show the raw means. For all variables, differences were considered statistically significant when $P<0.05$ and a tendency when $0.05<$ $P \leq 0.10$.

\section{RESULTS}

\section{Milking-Induced Hormone Release}

The concentrations of OT, PRL, and Cort in plasma varied with time relative to milking unit attachment (Figure 1; $P<0.001$ ). The concentration of OT rapidly and markedly increased from $68.5 \pm 5.8 \mathrm{pg} / \mathrm{mL}$ before the beginning of milking to $380.4 \pm 85.8 \mathrm{pg} / \mathrm{mL}$ at $4.3 \pm 1$ min after milking unit attachment. The OT concentration remained high and stable until the end of milking; it then markedly and quickly decreased, returning to the basal concentration between 15 and $25 \mathrm{~min}$ after the beginning of milking. The AUC of OT represented 2,527 $\pm 673 \mathrm{pg} / \mathrm{mL} \times 15 \mathrm{~min}$ (Table $1)$. The plasma concentrations of OT were highly variable among cows during milking and slightly variable after milking (see Supplemental Figure S1; https:// doi.org/10.3168/jds.2017-13166). The milking-induced increase in the PRL concentration was slightly delayed compared with the increase in OT concentration. The concentration of PRL increased from $55.7 \pm 10.4 \mathrm{ng} /$ $\mathrm{mL}$ before milking unit attachment to $171.2 \pm 12.3 \mathrm{ng} /$ $\mathrm{mL}$ at $6.2 \pm 0.8 \mathrm{~min}$ after milking unit attachment $(P$ $<0.001$; Table 1$)$. The PRL concentration then gradually decreased $(P<0.001)$ and tended to return to the basal concentration 45 min after the beginning of milking $(P=0.054)$. The AUC of PRL represented 2,584 $\pm 544 \mathrm{ng} / \mathrm{mL} \times 45 \mathrm{~min}$. Compared with OT and PRL, the increase in Cort concentration occurred later relative to the beginning of milking. Every cow presented 2 Cort peaks at milking - a first peak at the beginning of milking and a second peak after the end of milking. For 3 cows, the first peak was larger than the second peak. Overall, as shown in Figure 1, the Cort concentration increased from $6.7 \pm 1.8 \mathrm{ng} / \mathrm{mL}$ before the beginning of milking to $13.0 \pm 2.0 \mathrm{ng} / \mathrm{mL}$ at $14.4 \pm 0.6 \mathrm{~min}$ after the beginning of milking $(P<0.001$; Table 1$)$. The 
Cort plasma concentration then decreased $(P<0.001)$ until, at $25 \mathrm{~min}$ after the beginning of milking, it had returned to the basal concentration $(P>0.10)$. The AUC of Cort represented $69 \pm 28 \mathrm{ng} / \mathrm{mL} \times 25 \mathrm{~min}$. Thereafter, the Cort concentration tended to decrease to a level below the basal level until 45 min after the beginning of milking $(P<0.10)$.

\section{Indicators of Mammary Epithelium Integrity}

The lactose concentration in plasma gradually increased from $29.1 \mathrm{mg} / \mathrm{L}$ before the beginning of milking to $34.1 \mathrm{mg} / \mathrm{L}$ at the end of milking (Figure 2; $P<$ 0.001). After the end of milking, the plasma lactose concentration gradually decreased until it had returned to the basal concentration 35 min after the beginning of milking $(P>0.10)$. At milking, on average, $95 \mathrm{mg} / \mathrm{L}$ $\times 45 \mathrm{~min}$ of lactose crossed the mammary epithelium from the milk to the blood (Table 2). The $\mathrm{Na}^{+}$concentration in milk did not vary between time points 1 and 4 of milking, but it was higher at time points 5,6 , and 7 (Table $3 ; P<0.01$ ). The concentration of $\mathrm{K}^{+}$in the milk remained stable between time points 1 and 3 and decreased thereafter, reaching its lowest value at time point $6(P<0.05)$. As a result, the $\mathrm{Na}^{+}: \mathrm{K}^{+}$ratio did not vary at the beginning of milking and was greater at time point $6(P<0.01)$. The maximal concentration of plasma lactose and the maximal $\mathrm{Na}^{+}: \mathrm{K}^{+}$ratio in milk were positively correlated $(\mathrm{r}=0.67 ; P<0.05)$. Finally, the milk albumin content was lower at time point 5 of milking than at the first 3 time points of milking.

\section{Milk Yield and Composition}

The volume and composition of milk varied greatly during milking (Table 4; $P<0.001$ ). Milk yield increased until time point 3 and then gradually decreased as milking progressed. The fat content of the milk progressively increased from 6.9 to $78.9 \mathrm{~g} / \mathrm{kg}(P<0.001)$, whereas the protein content of the milk progressively decreased from 28.1 to $25.9 \mathrm{~g} / \mathrm{kg}(P<0.001)$. The lactose content decreased from time point 3 until the end of milking $(P<0.001)$.

\section{Milk Somatic Cells and Exfoliated MEC}

The SCC decreased between time points 1 and 2 of milking. The SCC then progressively increased from $25 \times 10^{3}$ cells $/ \mathrm{mL}$ at time point 2 to $126 \times 10^{3}$ cells $/$ $\mathrm{mL}$ at the end of milking, representing a $500 \%$ increase over the course of milking (Table $4 ; P<0.001$ ). The concentration of MEC in milk tended to vary during the course of milking. The concentration of MEC first decreased between time points 1 and 2 of milking and
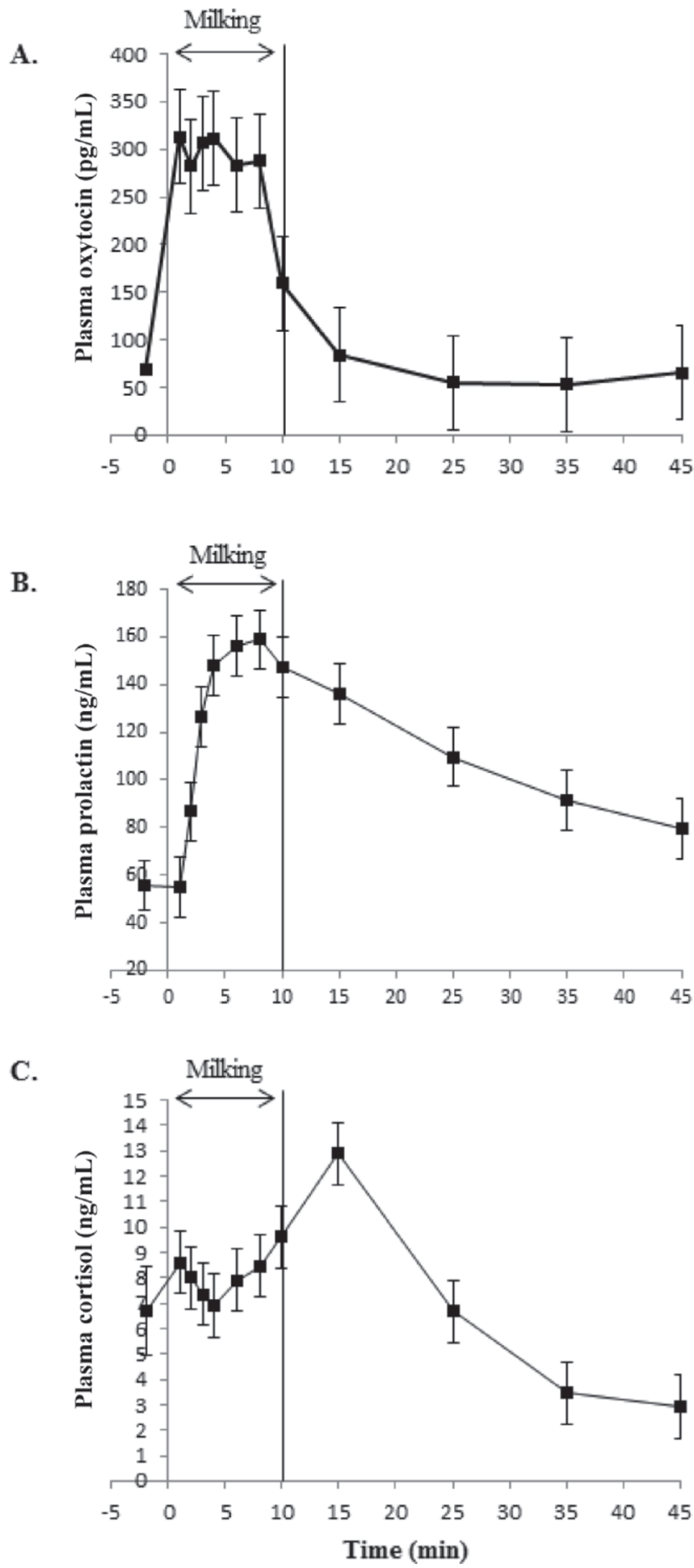

Figure 1. Plasma concentrations of (A) oxytocin, (B) prolactin, and $(\mathrm{C})$ cortisol before, during, and after milking relative to milking unit attachment $(\mathrm{t}=0)$ in 9 Holstein dairy cows. Data were analyzed using the SAS Mixed procedure with repeated statements (SAS Institute Inc., Cary, NC). Time was used as the repeated parameter, and cow was used as the subject for repeated measure. The duration of milking of each cow and the basal concentration of oxytocin, prolactin, or cortisol (calculated as the average concentration at 5 and $2 \mathrm{~min}$ before the onset of milking) were used as covariates. Time effect: $P$ $<0.001$. Data are presented as the means estimated by the statistical model \pm SEM. 
Table 1. Characteristics (raw means \pm SEM) of oxytocin, prolactin, and cortisol release at milking in 9 Holstein dairy cows

\begin{tabular}{lccc}
\hline Item & Oxytocin & Prolactin & Cortisol \\
\hline Basal concentration $^{1}$ & $68.5 \pm 5.8 \mathrm{pg} / \mathrm{mL}$ & $55.7 \pm 10.4 \mathrm{ng} / \mathrm{mL}$ & $6.7 \pm 1.8 \mathrm{ng} / \mathrm{mL}$ \\
Maximal concentration $_{\text {Delta }}{ }^{2}$ & $380.4 \pm 85.8 \mathrm{pg} / \mathrm{mL}$ & $171.2 \pm 12.3 \mathrm{ng} / \mathrm{mL}$ & $13.0 \pm 2.0 \mathrm{ng} / \mathrm{mL}$ \\
Time $^{\text {of maximal concentration }}$ & $312.0 \pm 82.1 \mathrm{pg} / \mathrm{mL}$ & $115.5 \pm 12.6 \mathrm{ng} / \mathrm{mL}$ & $6.5 \pm 1.2 \mathrm{ng} / \mathrm{mL}$ \\
AUC $^{3}$ & $4.3 \pm 1.0 \mathrm{~min}$ & $6.2 \pm 0.8 \mathrm{~min}$ & $14.4 \pm 0.6 \mathrm{~min}$ \\
& $2,527 \pm 673 \mathrm{pg} / \mathrm{mL} \times 15 \mathrm{~min}$ & $2,584 \pm 544 \mathrm{ng} / \mathrm{mL} \times 45 \mathrm{~min}$ & $69 \pm 28 \mathrm{ng} / \mathrm{mL} \times 25 \mathrm{~min}$ \\
\hline
\end{tabular}

${ }^{1}$ Corresponds to the average plasma concentration of oxytocin, prolactin, and cortisol at 5 and 2 min before attachment of the milking unit.

${ }^{2}$ Corresponds to the differences between the maximal and basal concentrations of oxytocin, prolactin, and cortisol.

${ }^{3}$ Area under the curve from the beginning of milking to 15 min after the beginning of milking for oxytocin, 45 min for prolactin, and 25 min for cortisol after subtracting the basal concentration.

then increased by $230 \%$ from time point 2 to the end of milking (Table 5; $P=0.10$ ). However, this increase was lower than the increase in the SCC, resulting in a progressive decrease in the percentage of MEC among the total milk somatic cells during the time course of milking (Table 5; $P<0.05$ ). In parallel, the number of leukocytes as a percentage of the total somatic cells increased. The total number of somatic cells in the milk increased between min 2 and the middle of milking and decreased at the end of milking $(P<0.05$; Table 4$)$. In parallel, the number of MEC in the milk remained stable until the middle of milking and was the lowest at the end of milking $(P<0.01$; Table 5$)$. The proportion of viable MEC and apoptotic MEC exfoliated in milk did not vary during milking $(P>0.10$; Table 5$)$ and

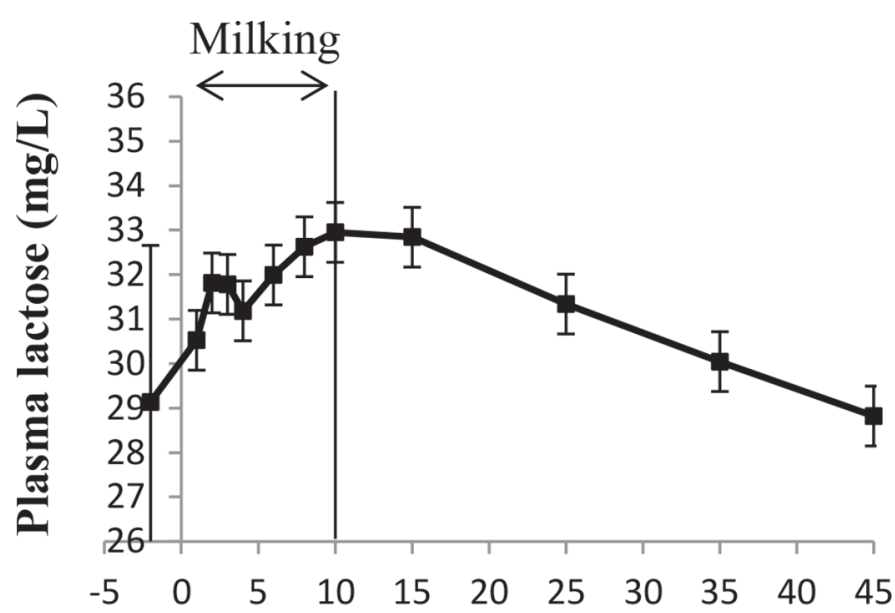

\section{Time (min)}

Figure 2. Plasma concentrations of lactose before, during, and after milking relative to milking unit attachment $(\mathrm{t}=0)$ in 9 Holstein dairy cows. Data were analyzed using the SAS Mixed procedure with repeated statements (SAS Institute Inc., Cary, NC). Time was used as the repeated parameter, and cow was used as the subject for repeated measure. The duration of milking of each cow and the basal lactose concentration were used as covariates. Data are presented as the means estimated by the statistical model \pm SEM. Time effect: $P$ $<0.001$. represented on average 50 and $35 \%$ of the total exfoliated MEC, respectively.

\section{Association Between Hormonal Status, Mammary Epithelium Integrity, and Exfoliation Rate During Milking}

The rate of MEC exfoliation at milking was negatively correlated with the AUC of Cort 25 min after the beginning of milking and with the Cort delta ( $\mathrm{r}$ $=-0.70$ and -0.77 , respectively; $P<0.05$ ). No correlation was found between the MEC exfoliation rate at milking and PRL and OT release or indicators of mammary epithelium integrity.

\section{DISCUSSION}

Consistent with the results of several previous studies, in the present study OT was found to be released into the blood during milking in response to tactile stimulation of the teat (Bruckmaier et al., 1993; Lollivier and Marnet, 2005). The plasma concentration of OT dramatically increased at the beginning of milking and remained elevated throughout milking. As previously reported, the plasma concentration of PRL increased to its maximal value approximately 6 min after the beginning of milking, whereas the maximal plasma

Table 2. Characteristics of plasma lactose at milking in 9 Holstein dairy cows

\begin{tabular}{|c|c|c|}
\hline Item & Mean & SEM \\
\hline Basal lactose concentration $^{1}(\mathrm{mg} / \mathrm{L})$ & 29.1 & 3.5 \\
\hline Maximal lactose concentration (mg/L) & 34.1 & 3.6 \\
\hline Lactose delta $^{2}(\mathrm{mg} / \mathrm{L})$ & 4.9 & 0.7 \\
\hline Time of maximal concentration (min) & 13.7 & 3.5 \\
\hline $\mathrm{AUC}^{3}(\mathrm{mg} / \mathrm{L} \times 45 \mathrm{~min})$ & 95 & 26 \\
\hline
\end{tabular}

${ }^{1}$ Corresponds to the average plasma concentration of lactose at 5 and 2 min before attachment of the milking unit.

${ }^{2}$ Corresponds to the difference between the maximal and basal concentrations of lactose.

${ }^{3}$ Area under the curve from the beginning of milking to 45 min after the beginning of milking after subtracting the basal concentration. 


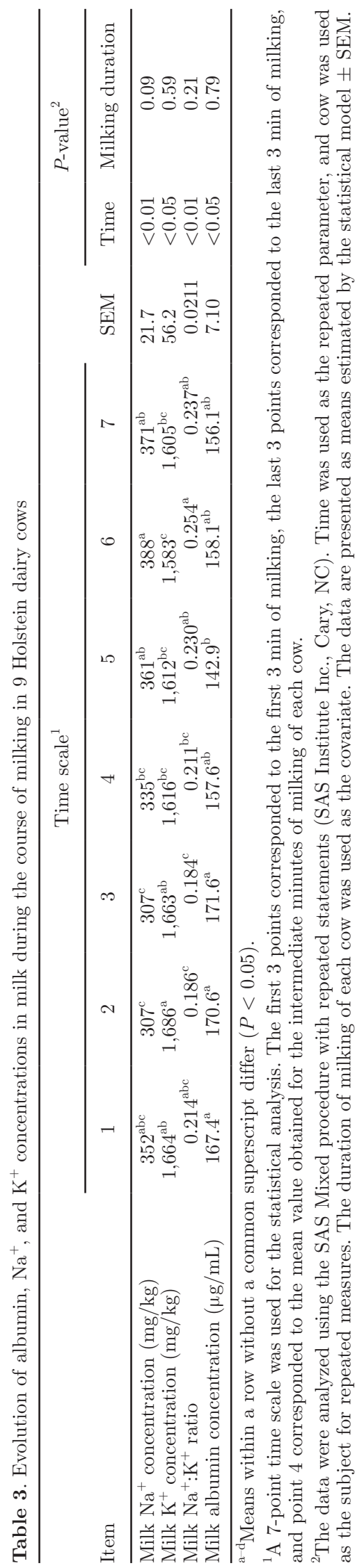

Cort concentration occurred after the end of milking (i.e., 14 min after the beginning of milking; Bruckmaier et al., 1993; Rushen et al., 2001; Negrão et al., 2004; Lollivier and Marnet, 2005). We hypothesized that the release of hormones during milking might regulate tight junction permeability. The tightness of the mammary epithelial barrier was assessed through several indicators. Lactose, which is synthesized exclusively by MEC, can be transferred from milk to blood only via a paracellular pathway through disrupted tight junctions (Kuhn and Linzell, 1970). The $\mathrm{Na}^{+}: \mathrm{K}^{+}$ratio in milk is known to be inversely correlated with mammary epithelium integrity during lactation (Sorensen et al., 2001). In the present study, the observed variations in the albumin concentration in milk during milking were not consistent with the observed variations in plasma lactose and milk $\mathrm{Na}^{+}: \mathrm{K}^{+}$ratio. This result confirms that milk albumin content is not a valuable marker for assessing mammary epithelium integrity, especially because albumin is synthesized by MEC and secreted into milk (Shamay et al., 2005). During milking, the lactose concentration in plasma and the $\mathrm{Na}^{+}: \mathrm{K}^{+}$ratio in milk increased progressively, and both reached maximal values at the end of milking, showing for the first time that the opening of tight junctions occurred throughout milking. The degree of tight junction opening may be greater during milk accumulation than during milking because greater basal concentrations of plasma lactose were observed when milk accumulation occurred over a long milking interval (Guinard-Flament et al., 2011). Interestingly, variations among individuals in the degree of tight junction opening were suggested by the positive correlation between the maximal concentration of plasma lactose and the maximal $\mathrm{Na}^{+}: \mathrm{K}^{+}$ratio in milk. The opening of tight junctions during milking occurred when OT concentrations were high. Given that exogenous and supraphysiological OT treatment is known to induce tight junction opening in dairy cows (Allen, 1990; Werner-Misof et al., 2007), the milkinginduced OT release could be responsible for the disruption of mammary epithelium integrity during milking. The fact that the lactose concentration returned to its basal concentration after the end of milking shows that the integrity of the mammary epithelium was recovered after the end of milking. The recovery of mammary epithelium integrity occurred after the observed increase in Cort concentration. Thus, Cort may induce the recovery of the mammary epithelium integrity after the end of milking; this is consistent with the known positive effects of Cort on tight junction closure in vitro (Zettl et al., 1992; Singer et al., 1994) and in vivo (Stelwagen et al., 1998; Nguyen et al., 2001). This study demonstrates for the first time that milking is associated with a transitory increase in the mammary 
Table 4. Evolution of yield and composition of milk collected each minute separately during the course of milking in 9 Holstein dairy cows

\begin{tabular}{|c|c|c|c|c|c|c|c|c|c|c|}
\hline \multirow[b]{2}{*}{ Item } & \multicolumn{7}{|c|}{ Time scale $^{1}$} & \multirow[b]{2}{*}{ SEM } & \multicolumn{2}{|r|}{$P$-value ${ }^{2}$} \\
\hline & 1 & 2 & 3 & 4 & 5 & 6 & 7 & & Time & Milking duration \\
\hline Milk yield (kg) & $2.9^{\mathrm{e}}$ & $3.6^{\mathrm{ce}}$ & $3.9^{\mathrm{cd}}$ & $3.3^{\mathrm{ce}}$ & $1.2^{\mathrm{b}}$ & $0.5^{\mathrm{ab}}$ & $0.3^{\mathrm{a}}$ & 0.28 & $<0.001$ & $<0.01$ \\
\hline Milk protein content $(\mathrm{g} / \mathrm{kg})$ & $28.1^{\mathrm{a}}$ & $27.5^{\mathrm{b}}$ & $27.4^{\mathrm{b}}$ & $27.1^{\mathrm{bc}}$ & $26.7^{\mathrm{cd}}$ & $26.4^{\text {de }}$ & $25.9^{\mathrm{e}}$ & 0.36 & $<0.001$ & 0.27 \\
\hline Lactose content $(\mathrm{g} / \mathrm{kg})$ & $51.8^{\mathrm{a}}$ & $52.2^{\mathrm{a}}$ & $51.6^{\mathrm{a}}$ & $50.0^{\mathrm{b}}$ & $48.4^{\mathrm{c}}$ & $47.9^{\mathrm{c}}$ & $47.2^{\mathrm{d}}$ & 0.39 & $<0.001$ & 0.95 \\
\hline $\log _{10} \mathrm{SCC}$ & $4.7^{\mathrm{a}}$ & $4.4^{\mathrm{b}}$ & $4.5^{\mathrm{b}}$ & $4.8^{\mathrm{ac}}$ & $4.8^{\mathrm{ac}}$ & $5.0^{\mathrm{cd}}$ & $5.1^{\mathrm{d}}$ & 0.20 & $<0.001$ & 0.98 \\
\hline
\end{tabular}

${ }^{\mathrm{a}-\mathrm{f}}$ Means within a row without a common superscript differ $(P<0.05)$.

${ }^{1}$ A 7-point time scale was used for the statistical analysis. The first 3 points corresponded to the first 3 min of milking, the last 3 points corresponded to the last $3 \mathrm{~min}$ of milking, and point 4 corresponded to the mean value obtained for the intermediate minutes of milking of each cow. ${ }^{2}$ The data were analyzed using the SAS Mixed procedure with repeated statements (SAS Institute Inc., Cary, NC). Time was used as the repeated parameter, and cow was used as the subject for repeated measures. The duration of milking of each cow was used as the covariate. The data are presented as means estimated by the statistical model \pm SEM.

epithelial permeability that is likely regulated by the release of OT and Cort.

The variations in the composition of milk during milking observed in our study are consistent with the data reported in the literature (Vangroenweghe et al., 2002; Ontsouka et al., 2003; Sarikaya et al., 2005). The fat content of milk gradually increased from the beginning to the end of milking, whereas the protein and lactose contents of the milk decreased throughout milking. Milk also contains a variety of somatic cell types, namely MEC and leukocytes (lymphocytes, macrophages, neutrophils, and eosinophils). The observed variations in SCC during milking (i.e., a decrease at the beginning of milking followed by a marked increase at the end of milking) were also in agreement with reports from previous studies in which SCC was shown to be high in the cisternal fraction and lowest in the first alveolar fraction and to increase gradually during alveolar milk ejection (Ontsouka et al., 2003; Sarikaya et al., 2005). To our knowledge, this experiment is the first one describing the variations of the number and the concentration of MEC during the time course of milking. An average of $125 \times 10^{6}$ MEC were exfoliated in 1 milking, a value that is consistent with the reported daily exfoliation rate of between 200 and 390 $\times 10^{6}$ MEC exfoliated per day with 2 milkings (Lollivier et al., 2015; Herve et al., 2016). Moreover, half of the MEC exfoliated during milking were living cells, indicating that the exfoliation process makes it possible to eliminate not only apoptotic but also living MEC. During min 1 of milking, an average of $17 \times 10^{6} \mathrm{MEC}$ were exfoliated into the milk; this represented $13 \%$ of the total MEC exfoliated during milking. The milk obtained during min 1 of milking is likely to have been cisternal milk that accumulated between 2 milkings. Indeed, milk yield averaged $2.9 \mathrm{~kg}$, which represents the average yield of cisternal milk in dairy cows (Ayadi et al., 2003). Therefore, the presence of MEC in the

Table 5. Evolution of concentration, number, and viability of milk mammary epithelial cells (MEC) during the course of milking in 9 Holstein dairy cows

\begin{tabular}{|c|c|c|c|c|c|c|c|}
\hline \multirow[b]{2}{*}{ Item } & \multicolumn{4}{|c|}{ Time scale $^{1}$} & \multirow[b]{2}{*}{ SEM } & \multicolumn{2}{|c|}{$P$-value ${ }^{2}$} \\
\hline & 1 & 2 & Middle & End & & Time & Milking duration \\
\hline Milk MEC $\left(10^{3}\right.$ cells $\left./ \mathrm{mL}\right)$ & $7.2^{\mathrm{a}}$ & $3.3^{\mathrm{b}}$ & $5.1^{\mathrm{ab}}$ & $7.5^{\mathrm{a}}$ & 2.65 & 0.10 & 0.57 \\
\hline $\log _{10}$ milk MEC number 3 & $7.1^{\mathrm{a}}$ & $6.9^{\mathrm{a}}$ & $7.0^{\mathrm{a}}$ & $6.7^{\mathrm{b}}$ & 0.15 & $<0.01$ & 0.14 \\
\hline MEC in milk cells (\%) & $26.3^{\mathrm{ab}}$ & $32.4^{\mathrm{a}}$ & $21.1^{\mathrm{bc}}$ & $14.1^{\mathrm{cd}}$ & 4.86 & $<0.05$ & 0.43 \\
\hline Milk MEC viability (\%) & 54.3 & 50.2 & 50.2 & 45.0 & 5.49 & 0.52 & 0.68 \\
\hline Apoptotic cells (\%) & 33.0 & 33.4 & 34.9 & 38.2 & 6.11 & 0.51 & 0.96 \\
\hline
\end{tabular}

\footnotetext{
${ }^{\mathrm{a}-\mathrm{d}}$ Means within a row without a common superscript differ $(P<0.05)$.
}

${ }^{1} \mathrm{~A} 4$-point time scale corresponding to the sample collected at min 1 , min 2 , the middle of milking (corresponding to min $5 \pm 1$ of milking), and the end of milking (corresponding to min $7 \pm 2$ of milking) was used for the statistical analysis.

${ }^{2}$ The data were analyzed using the SAS Mixed procedure with repeated statements (SAS Institute Inc., Cary, NC). Time was used as the repeated parameter, and cow was used as the subject for repeated measures. The duration of milking of each cow was used as the covariate. The data are presented as means estimated by the statistical model \pm SEM.

${ }^{3}$ The milk MEC number was determined by multiplying the milk MEC concentration by the milk yield. The data were not normally distributed; therefore, $\log _{10}$ transformation was performed before the analyses. 
milk sample taken during min 1 of milking suggests that MEC could have been left over from the previous milking or exfoliated as a result of the shedding from the epithelium into the cisternal milk between milkings in the absence of mechanical pressure caused by milking-induced OT release. The remaining fraction of the exfoliated MEC (i.e., $87 \%$ of the total number of exfoliated MEC) was present in the milk collected from min 2 to the end of milking, which likely corresponded to the alveolar milk.

At this time, the mechanisms that result in the presence of MEC in alveolar milk are not clear. The first hypothesis is that these MEC are continuously exfoliated between each of 2 successive milkings, trapped in the alveolar lumen, and transferred along the mammary duct to the cistern only during the alveolar milk ejection process. Indeed, the MEC exfoliation process could be comparable with that suggested for fat globule delivery due to the size of MEC (i.e., $20 \mu \mathrm{m}$ on average) or to capillary and adhesive forces that occur during the milking process; the latter could influence MEC transfer by positive and negative membrane potentials (Sarikaya et al., 2005). Mammary epithelial cell ejection could also occur during the ejection of fat globules due to the hydrophobic properties of somatic cells (Nielsen et al., 2005). These phenomena could explain why most of the MEC are present in the alveolar fraction. The second hypothesis regarding the presence of MEC in alveolar milk is that MEC exfoliation occurs during milking as a consequence of the mechanical forces exerted on the mammary epithelium and a disruption of the mammary epithelium integrity, both of which are caused by milking-induced OT release. In support of this hypothesis, we previously showed that greater exfoliation rates are associated with mammary epithelium disruption (Herve et al., 2016). In the present study, we showed that milking induces mammary epithelium disruption in response to OT release. However, no relationship could be established between any variable describing OT release (basal or maximal concentrations, delta, or AUC), indicators of mammary epithelium disruption, and the MEC exfoliation rate at milking. It has recently been shown that fat globules are secreted following OT stimulation (Masedunskas et al., 2017), suggesting that the progressive increase in fat content in consecutive milk fractions during milking is attributable to active secretion of fat globules during milking. If again we may draw a parallel between fat content and MEC concentration in milk, these findings argue in favor of MEC exfoliation during milking and against the accumulation of MEC in the alveolar milk fraction between milkings. Administration of an OT receptor antagonist such as atosiban, which is known to inhibit the OT-induced contraction of myoepithelial cells in dairy cows (Bruckmaier et al., 1997), could offer a tool for investigating the role of OT in regulating the MEC exfoliation process during milking. These 2 hypotheses concerning MEC exfoliation, one viewing it as a continuous mechanism and the other viewing it as a process stimulated by milking, are not mutually exclusive.

The presence of MEC in milk throughout the milking process was concomitant with the release of PRL. The MEC exfoliation process could be partly regulated by PRL; however, no correlation between PRL release and the MEC exfoliation rate at milking was observed. Nevertheless, the MEC concentration in milk increased during milking even when the plasma concentration of PRL was high. This finding contrasts with the known inhibitory effect of PRL on MEC exfoliation during lactation (Lollivier et al., 2015) and mammary involution (Boutinaud et al., 2013). The release of PRL following OT release could limit the stimulatory effect of OT on the MEC exfoliation process via stimulation of the expression of genes involved in tight junction formation, as has been previously suggested in rodents (Gass et al., 2003).

Finally, to date, there is no evidence that Cort plays a role in regulating the MEC exfoliation process. The Cort concentration peaked at the end of milking; therefore, Cort may limit MEC exfoliation by reducing mammary epithelial permeability following the end of milking. Furthermore, in the present study, the MEC exfoliation rate at milking was negatively correlated with the AUC for Cort and with the Cort delta, suggesting that Cort may play a role in limiting the MEC exfoliation process. Further investigations are needed to study the potential role of Cort in regulating MEC exfoliation.

\section{CONCLUSIONS}

This study demonstrated that a transitory disruption of the mammary epithelium integrity that could be induced by OT and restored by Cort occurs during milking. A small proportion of MEC were exfoliated into cisternal milk, left over from the previous milking or as a result of the shedding from the epithelium in the absence of the mechanical pressures caused by milkinginduced OT release. However, most of the exfoliated MEC were present in the alveolar fraction. These MEC could have been either continuously exfoliated and delivered from the alveolar lumen during the milk ejection process or exfoliated during milking as a consequence of the OT-induced mechanical forces and a disruption of the mammary epithelium integrity or both. 


\section{ACKNOWLEDGMENTS}

The authors are very grateful to Philippe Lamberton, Daniel Chevrel, André Cozien, Jean-Yves Thébault, Pierre-Yves Pennober, Jean-Luc Harel, and Maryvonne Texier of the Physiology Team of the INRA experimental farm of Méjusseaume (INRA UMR PEGASE, Le Rheu, France) for caring for the animals and assisting with blood and milk sampling. The authors also thank Sandra Wiart, Sabrina Philau, Colette Mustière, and Morgane Kerboas (INRA UMR PEGASE, Saint Gilles, France) for technical assistance; Clément Cirot (INRA UMR PEGASE, Saint Gilles, France) for help with the statistical analyses; and Pierre-Guy Marnet (Agrocampus-Ouest, Rennes, France) for providing the antibody and the label for oxytocin assays. This study was conducted with the financial support of the GALA association (Janzé, France) and INRA through the RUMINFLAME project funded by the GISA metaprogram 2012. Lucile Herve was supported by a PhD studentship funded by Région Bretagne and Agrocampus-Ouest (Rennes, France).

\section{REFERENCES}

Allen, J. C. 1990. Milk synthesis and secretion rates in cows with milk composition changed by oxytocin. J. Dairy Sci. 73:975-984.

Ayadi, M., G. Caja, X. Such, and C. H. Knight. 2003. Use of ultrasonography to estimate cistern size and milk storage at different milking intervals in the udder of dairy cows. J. Dairy Res. 70:1-7. https://doi.org/10.1017/S0022029902005873.

Boutinaud, M., M. H. Ben Chedly, E. Delamaire, and J. GuinardFlament. 2008. Milking and feed restriction regulate transcripts of mammary epithelial cells purified from milk. J. Dairy Sci. 91:988998. https://doi.org/10.3168/jds.2007-0587.

Boutinaud, M., J. Guinard-Flament, and H. Jammes. 2004. The number and activity of mammary epithelial cells, determining factors for milk production. Reprod. Nutr. Dev. 44:499-508. https://doi .org/10.1051/rnd:2004054.

Boutinaud, M., N. Isaka, A. Deflandre, E. Gandemer, P.-G. Marnet, F. Dessauge, and V. Lollivier. 2013. Prolactin-inhibitor cabergoline enhanced the mammary remodeling during drying-off in dairy cows. J. Anim. Sci. 91(E-Suppl. 2):151.

Bruckmaier, R. M., D. Schams, and J. W. Blum. 1992. Aetiology of disturbed milk ejection in parturient primiparous cows. J. Dairy Res. 59:479-489.

Bruckmaier, R. M., D. Schams, and J. W. Blum. 1993. Milk removal in familiar and unfamiliar surroundings: Concentrations of oxytocin, prolactin, cortisol and $\beta$-endorphin. J. Dairy Res. 60:449-456. https://doi.org/10.1017/S0022029900027813.

Bruckmaier, R. M., O. Wellnitz, and J. W. Blum. 1997. Inhibition of milk ejection in cows by oxytocin receptor blockade, $\alpha$-adrenergic receptor stimulation and in unfamiliar surroundings. J. Dairy Res. $64: 315-325$.

Capuco, A. V., S. E. Ellis, S. A. Hale, E. Long, R. A. Erdman, X. Zhao, and M. J. Paape. 2003. Lactation persistency insights from mammary cell proliferation studies. J. Anim. Sci. 81:18-31.

Flint, D. J., and M. Gardner. 1994. Evidence that growth hormone stimulates milk synthesis by direct action on the mammary gland and that prolactin exerts effects on milk secretion by maintenance of mammary deoxyribonucleic acid content and tight junction status. Endocrinology 135:1119-1124.
Gass, S., J. Harris, C. Ormandy, and C. Brisken. 2003. Using gene expression arrays to elucidate transcriptional profiles underlying prolactin function. J. Mammary Gland Biol. Neoplasia 8:269-285.

Guinard-Flament, J., Y. Gallard, and H. Larroque. 2011. Lactose in blood plasma and the ability of dairy cows to tolerate once-daily milking in terms of milk loss and milk recovery. J. Dairy Sci. 94:3446-3454. https://doi.org/10.3168/jds.2010-4081.

Herve, L., H. Quesnel, V. Lollivier, and M. Boutinaud. 2016. Regulation of cell number in the mammary gland by controlling the exfoliation process in milk in ruminants. J. Dairy Sci. 99:854-863. https://doi.org/10.3168/jds.2015-9964.

Kitchen, B. J. 1981. Bovine mastitis: Milk compositional changes and related diagnostic tests. J. Dairy Res. 48:167-188. https://doi.org/ 10.1017/S0022029900021580.

Komara, M., and P. G. Marnet. 2009. Endocrine responses and milk emission characteristics in high yielding Alpine dairy goats under once daily milking management. Small Rumin. Res. 87:64-69. https://doi.org/10.1016/j.smallrumres.2009.10.003.

Kuhn, N. J., and J. L. Linzell. 1970. Measurement of the quantity of lactose passing into mammary venous plasma and lymph in goats and in a cow. J. Dairy Res. 37:203-208. https://doi.org/10.1017/ S002202990001325X.

Linzell, J. L., M. Peaker, and J. C. Taylor. 1975. The effects of prolactin and oxytocin on milk secretion and on the permeability of the mammary epithelium in the rabbit. J. Physiol. 253:547-563.

Lollivier, V., P. Lacasse, J. Angulo Arizala, P. Lamberton, S. Wiart, J. Portanguen, R. Bruckmaier, and M. Boutinaud. 2015. In vivo inhibition followed by exogenous supplementation demonstrates galactopoietic effects of prolactin on mammary tissue and milk production in dairy cows. J. Dairy Sci. 98:8775-8787. https://doi .org/10.3168/jds.2015-9853.

Lollivier, V., and P.-G. Marnet. 2005. Galactopoietic effect of milking in lactating Holstein cows: Role of physiological doses of oxytocin. Livest. Prod. Sci. 95:131-142. https://doi.org/10.1016/j.livprodsci .2005.01.013.

Marnet, P. G., H. Volland, P. Pradelles, J. Grassi, and M. Beaufils. 1994. Subpicogram determination of oxytocin by an enzyme immunoassay using acetylcholinesterase as label. J. Immunoassay 15:35-53. https://doi.org/10.1080/15321819408009570.

Masedunskas, A., Y. Chen, R. Stussman, R. Weigert, and I. H. Mather. 2017. Kinetics of milk lipid droplet transport, growth, and secretion revealed by intravital imaging: Lipid droplet release is intermittently stimulated by oxytocin. Mol. Biol. Cell 28:935-946.

Murthy, G. K., and U. Rhea. 1967. Determination of major cation in milk by atomic absorption spectrophotometry. J. Dairy Sci. 50:313-317.

Negrão, J. A., M. A. Porcionato, A. M. De Passille, and J. Rushen. 2004. Cortisol in saliva and plasma of cattle after ACTH administration and milking. J. Dairy Sci. 87:1713-1718.

Nguyen, D. A., and M. C. Neville. 1998. Tight junction regulation in the mammary gland. J. Mammary Gland Biol. Neoplasia 3:233246.

Nguyen, D. A., A. F. Parlow, and M. C. Neville. 2001. Hormonal regulation of tight junction closure in the mouse mammary epithelium during the transition from pregnancy to lactation. J. Endocrinol. 170:347-356.

Nielsen, N. I., T. Larsen, M. Bjerring, and K. L. Ingvartsen. 2005. Quarter health, milking interval, and sampling time during milking affect the concentration of milk constituents. J. Dairy Sci. 88:3186-3200.

Ontsouka, C. E., R. M. Bruckmaier, and J. W. Blum. 2003. Fractionized milk composition during removal of colostrum and mature milk. J. Dairy Sci. 86:2005-2011.

Rushen, J., L. Munksgaard, P. G. Marnet, and A. M. De Passillé. 2001. Human contact and the effects of acute stress on cows at milking. Appl. Anim. Behav. Sci. 73:1-14.

Sarikaya, H., C. Werner-Misof, M. Atzkern, and R. M. Bruckmaier. 2005. Distribution of leucocyte populations, and milk composition, in milk fractions of healthy quarters in dairy cows. J. Dairy Res. 72:486-492. https://doi.org/10.1017/S0022029905001317. 
Shamay, A., R. Homans, Y. Fuerman, I. Levin, H. Barash, N. Silanikove, and S. J. Mabjeesh. 2005. Expression of albumin in nonhepatic tissues and its synthesis by the bovine mammary gland. J. Dairy Sci. 88:569-576.

Singer, K. L., B. R. Stevenson, P. L. Woo, and G. L. Firestone. 1994 Relationship of serine/threonine phosphorylation/dephosphorylation signaling to glucocorticoid regulation of tight junction permeability and ZO-1 distribution in nontransformed mammary epithelial cells. J. Biol. Chem. 269:16108-16115.

Sorensen, B. A., D. D. Muir, and C. H. Knight. 2001. Thrice-daily milking throughout lactation maintains epithelial integrity and thereby improves milk protein quality. J. Dairy Res. 68:15-25.

Stelwagen, K., H. A. McFadden, and J. Demmer. 1999. Prolactin, alone or in combination with glucocorticoids, enhances tight junction formation and expression of the tight junction protein occludin in mammary cells. Mol. Cell. Endocrinol. 156:55-61.

Stelwagen, K., and K. Singh. 2014. The role of tight junctions in mammary gland function. J. Mammary Gland Biol. Neoplasia 19:131138. https://doi.org/10.1007/s10911-013-9309-1.

Stelwagen, K., D. C. Van Espen, G. A. Verkerk, H. A. McFadden, and V. C. Farr. 1998. Elevated plasma cortisol reduces permeability of mammary tight junctions in the lactating bovine mammary epithelium. J. Endocrinol. 159:173-178.
Vangroenweghe, F., H. Dosogne, and C. Burvenich. 2002. Composition and milk cell characteristics in quarter milk fractions of dairy cows with low cell count. Vet. J. 164:254-260. https://doi.org/10.1053/ tvjl.2002.0725.

Wall, S. K., O. Wellnitz, L. E. Hernández-Castellano, A. Ahmadpour, and R. M. Bruckmaier. 2016. Supraphysiological oxytocin increases the transfer of immunoglobulins and other blood components to milk during lipopolysaccharide- and lipoteichoic acid-induced mastitis in dairy cows. J. Dairy Sci. 99:9165-9173. https://doi .org/10.3168/jds.2016-11548.

Werner-Misof, C., M. W. Pfaffl, H. H. D. Meyer, and R. M. Bruckmaier. 2007. Effect of chronic oxytocin-treatment on the bovine mammary gland immune system. Vet. Med. (Praha) 52:475-486.

Yart, L., V. Lollivier, L. Finot, J. Dupont, S. Wiart, M. Boutinaud, P. G. Marnet, and F. Dessauge. 2013. Changes in mammary secretory tissue during lactation in ovariectomized dairy cows. Steroids 78:973-981. https://doi.org/10.1016/j.steroids.2013.06.003.

Zettl, K. S., M. D. Sjaastad, P. M. Riskin, G. Parry, T. E. Machen, and G. L. Firestone. 1992. Glucocorticoid-induced formation of tight junctions in mouse mammary epithelial cells in vitro. Proc. Natl. Acad. Sci. USA 89:9069-9073. 